DOI: http://dx.doi.org/10.20534/EJEMS-17-1-35-38

Tsintsadze Asie Enverovna,

Batumi Shota Rustaveli State University, Professor, the Faculty of Economics and Business

E-mail: asinsaze@rambler.ru

Phutkaradze Beka Zaurovich, Batumi Shota Rustaveli State University, PhD student, the Faculty of Economics and Business E-mail:b.phutkaradze@gmail.com

\title{
Financial globalization and economic development
}

Abstract: The purpose of this paper is to evaluate the impact of financial globalization on economic growth. Advantages and disadvantages have been analyzed, applying various theoretical aspects, as well as empirical data for the period of 2000-2011.

Keywords: Financial globalization, financial integration, GDP growth, developing countries.

The worldwide practice combines dozens of articles about how to stimulate economic growth and what factors contribute to this process. However, the majority of the studies are concentrated on country/region-specific problems and underline individual topics, such as the banking sector, the evolution of insurance industry, taxation, regulatory frameworks, etc. Despite the abundance of various papers, there is no clear and unambiguous answer on how globalization and financial integration affects economy.

The topic of financial globalization and its impact on socio-economic environment became popular among the world's leading economists over the past decades. Special attention was devoted to the case of developing countries. According to one of the most popular definition, financial globalization is the movement of foreign goods and services, foreign direct investments, foreign capital and commercial transactions between the domestic and international markets. In other words, it could be described as integration of local financial system with international financial markets and institutions [4].

Formation of world market and capitalistic systems, technological achievements in the field of communication and transportation, increased foreign economic activities between countries, production efficiency, sophistication of management and other economic/political factors have led to the creation of financial globalization. In addition, a significant contribution comes from development of financial markets, transnational corporations and international institutions.

There are different opinions regarding positive and negative aspects of globalization. Supporters talk about economic and technological achievements that accompany this process, while anti globalists, mainly, argue that globalization wiped out culture and identity of smaller countries, such as Georgia. Globalization allows people to benefit from free trade, satisfying customer requirements and utilizing world's resources in the most efficient way. All of this lead to increased competition, innovations and improved living standards. On the other hand, globalization deepens inequality and poverty, as well as significantly contributes to the creation of financial and currency crises.

According to research conducted by International Monetary Fund (IMF), in theory there are number of direct and indirect channels, through which financial integration (financial globalization) can have positive impact on economic growth in developing countries [2]. For instance, we can consider several direct factors from the same study:

1) Increase of domestic savings: because of augmented savings, the capital flow growths from developed to developing countries, which is beneficial for both sides. On the one hand, developing countries receive access to more money and are able to complete various projects. While, on the other side, developed countries receive higher return on investments, because such investments are considered to be more risky, and therefore, have higher profits. Ultimately, all of this diminishes risk-free rate in developing countries.

2) Fostering the development of domestic financial sector: international capital flows rise the liquidity of domestic stock markets. Foreign ownership of domestic banks can also be associated with various benefits. For 
example, the participation of foreign banks can increase an access to international financial markets. Besides, it helps to develop and improve the legal framework and control standards in the domestic banking industry. It should be mentioned as well, that in many cases, foreign banks introduce new financial products. All of this increases the level of competition and the quality of service on internal market.

3) Decrease in the cost of capital through better risk allocation: Financial globalization improves risk allocation process, which means that local and foreign investors have opportunity to diversify risks more efficiently. In addition, an increase of capital flow rises liquidity in the domestic
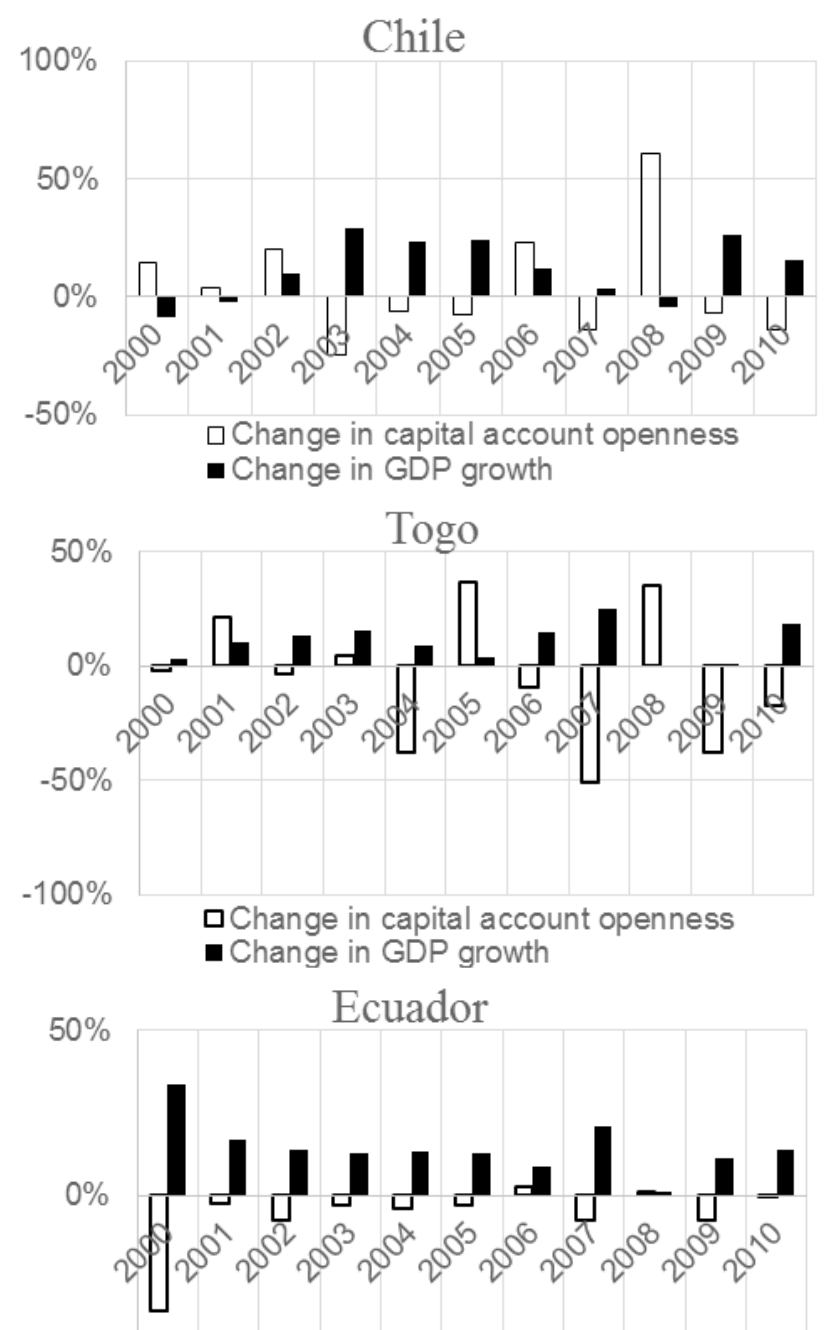

$-50 \%$

Change in capital account openness - Change in GDP growth stock market, which reduces the market risk premium in turn, therefore - cost of capital diminishes.

Despite abovementioned positive theoretical factors, numerous empirical studies conducted by economists, suggest that the relationship between economic growth and financial globalization is not necessarily positive. In particular, their results revealed to differ in some countries, having negative and partially positive correlation, as per IMF research [4]. Similarly, we conducted empirical analyses of several countries to evaluate the relationship between financial integration and GDP growth (see below charts). We utilized time-series data for the period of 2000-2011.

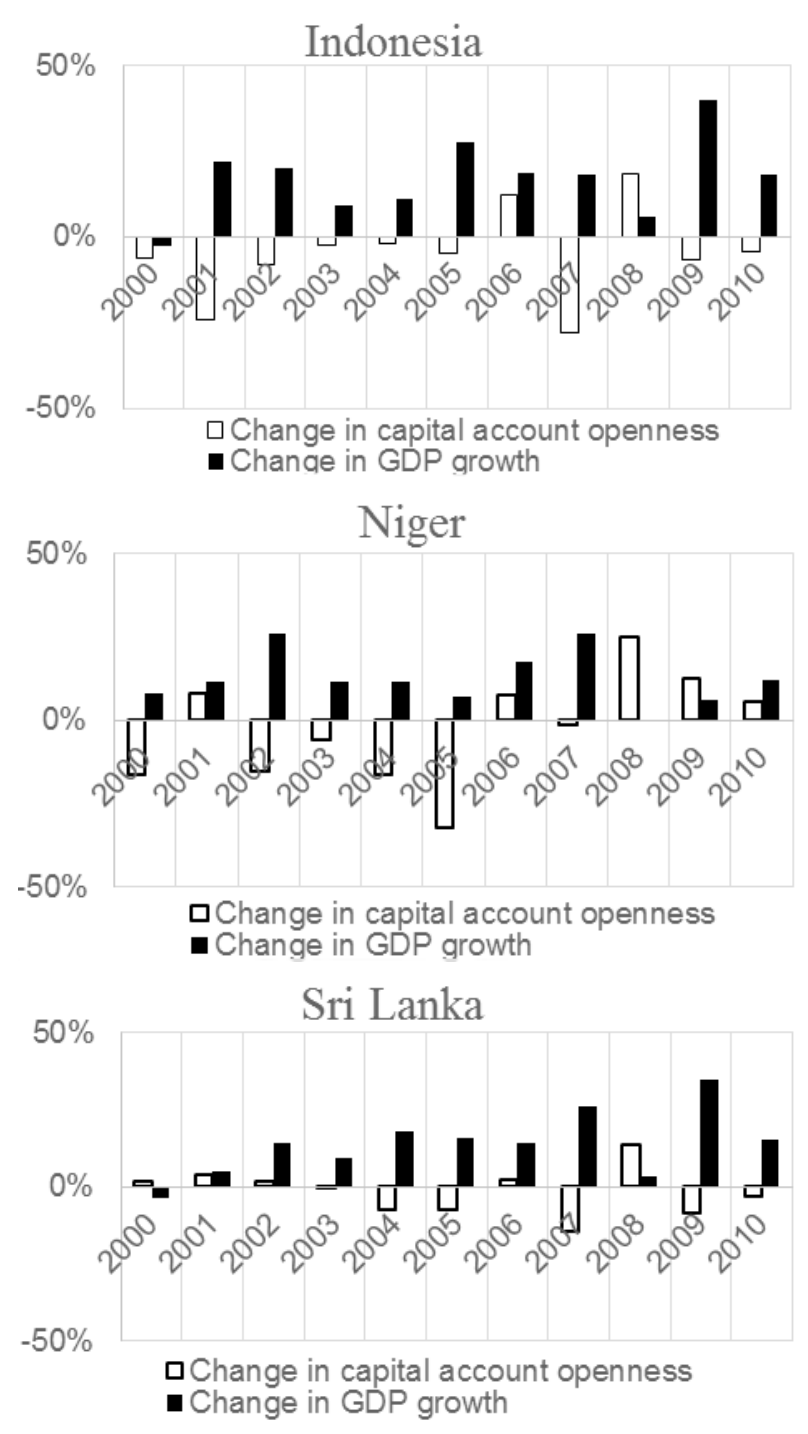

Figure 1.

Note $_{1}$ : Capital account openness is measured as a country's aggregate assets plus liabilities as a percentage of GDP, and includes the categories of foreign direct investment, portfolio equity investment, external debt, and official reserves.

Note $_{2}$ : GDP is in (current US\$).
Source: Own calculations based on the World Bank's World Development Indicators (WDI) Database and Lane \& Milesi-Ferretti's (2011) index (total).

As our results exposed, in some countries financial globalization and economic growth have negative correlation. This supports opinion that countries with no (or 
limited) financial integration can still achieve significant economic growth. This is clearly shown in the case of Indonesia. In year 2009 Indonesia's GDP growth reached $40 \%$, while its capital account openness was negative for the same year. Another conclusion, which can be derived from the charts above is, that financial integration is not sufficient condition for economic growth. As it is illustrated in Chile's example, the country's capital account openness has increased by $60 \%$ in 2008, while GDP growth was down by $4 \%$.

Furthermore, apart from direct impact-channels, the financial globalization is characterized by indirect factors, through which it stimulates economic growth. For instance, economists believe that the country's willingness towards financial integration can be seen as indicator of future loyal policy of attracting foreign investments. This can be expressed by creating a favorable environment for investors and various deregulation policies. Therefore, the country's readiness to become a part of financial globalization is considered as indirect impact factor on economy [2].

In our opinion, one of the most important factors of (financial) globalization is a psychological aspect, which also belongs to a group of an indirect impact channels. Rapid pace of development of globalization has led to the changes in psychology of consumers, business entities, managers and others.

Globalization provided opportunity for big companies and brands to develop further and become global leaders on the market. Consequently, nowadays people trust and consume better-known products, gradually becoming addicted to international brands. This further enhances the market position of big and transnational companies, and to some extent, prevents development of local products. On the other hand, however, contributes to the formation of competitive environment, and thus increases efficiency. Additionally, having vast choice of goods, globalization made consumers more wary, demanding and "pretentious". The worldwide threat of genetically modified products (GMO) has further increased consumers' precautions.
In line with enlarged competition and consumers' caution, entrepreneurs (companies) are forced to become more active and seek different ways for development, to meet local demand. Otherwise, they will be "swallowed" by bigger and stronger companies. Business entities are continuously trying to advance technologies, sophisticate their operations, improve efficiency indicator (s), seek opportunities to enter new markets etc. All this is caused by the psychological fear, which is based on raising awareness of globalization - "development, or financial collapse". Companies are conscious that without permanent development of their business, financial failure is imminent.

With amplified financial integration, management's psychology has experienced changes, as well. Proper management and timely/effective decision-making process is one of the vital factors in successful business environment. Accordingly, the management bodies are trying to devote more time and money to increase professionalism of their employees. The management's awareness, that the competence and "know-how" are essential, is that indirect factor, which is affected by financial globalization. On its turn, "know-how" is positively correlated with economic growth. However, it should be mentioned that economists [6] consider managerial "know-how" as a direct impact factor on economy. For instance, according to study conducted by IMF, financial integration escalates flow of foreign direct investments from one country to another. The accompanying element of this is a transfer of managerial knowledge. As a result, we get an increased level of productivity and economy.

To conclude, the impact of financial globalization varies across different countries, changing their economic environment. In our opinion, it is impossible to speak of the consequences of globalization in advance, since the globalization process itself is influenced by various economic and social factors. As a result, in assessment of advantages and disadvantages of financial integration the researchers should pay significant attention to the risks associated with the globalization process.

\section{References:}

1. Prasad E., Rogoff K., Wei S-J., Kose M.A. Financial Globalization and Economic Policies. - 2010.

2. Prasad E., Rogoff K., Wei S-J., Kose M.A.: Effects of Financial Globalization on Developing Countries: Some Empirical Evidence. - 2003.

3. Makhlouf H.H.: Facets of Globalization. -2014.

4. Awoyemi B., O., Jabar A. A. Financial Globalization: Economic Implications for Nigeria. - 2014.

5. Bumann S., Hermes N., Lensink R. Financial liberalisation and economic growth: A meta-analysis. - 2012.

6. Borensztein De Gregorio \& Lee How does foreign direct investment affect economic growth? - 1998. 
7. The World Bank, World Development Indicators, http://data.worldbank.org/data-catalog/world-developmentindicators retrieved on 09 January - 2017.

8. Philip R. Lane and Gian Maria Milesi-Ferretti (2007), “The external wealth of nations mark II: Revised and extended estimates of foreign assets and liabilities, - 1970-2004 ", Journal of International Economics 73, November, - 223-250; URL: http://www.philiplane.org/EWN.html retrieved on - 08 January - 2017. 